\title{
The Corpse Gives Life
}

\begin{abstract}
This chapter begins by looking at the trade in human fat into the nineteenth century, and how the control over its availability switched from the executioner to the anatomy schools. This, and other developments, led to the decline of the executioner-healer on the Continent. The similar trade in human skin for macabre mementos and magic is explored. The chapter then considers the history of the healing touch of the hanged man's hand in England, and the rise of blood-drinking at beheadings in nineteenth-century Germany and Scandinavia.
\end{abstract}

Keywords Human fat · Blood-drinking · Human skin · Hanged man's hand $\cdot$ Healing touch

The French journalist, Félix Pyat, observed humorously in 1841 that 'the executioner is a bit of a doctor, just as the doctor is a bit of an executioner'. ${ }^{1}$ However, by this time the role of the executioner-healer was vanishing. As Kathy Stuart has discussed with regard to Germany, during the early modern period the medical side of the executioners' profession had given the dishonourable trade an important route to social mobility. At least nine executioners' sons matriculated from the University of Ingolstadt, Bavaria, between 1680 and 1770, for instance. However, restrictions regarding executioner medicine, and the abolition of torture across western and central Europe during the late eighteenth century,

(C) The Author(s) 2017

O. Davies and F. Matteoni, Executing Magic in the Modern Era, 29

Palgrave Historical Studies in the Criminal Corpse and its Afterlife, DOI 10.1007/978-3-319-59519-1_3 
reduced the financial rewards of the trade, thereby limiting avenues for social advancement. ${ }^{2}$ In Spain, for example, a law of 1793 suppressed all the perquisites of the executioner, ending the sale of criminal corpse parts for medicine. ${ }^{3}$

The medical respectability of the executioner was, nevertheless, still evident during the early years of the nineteenth century, though in Britain there was no such tradition of physician-hangmen. The executioner of Lyon, named Chrétien, had a considerable reputation as a healer in the region, particularly for a secret unguent he sold for the treatment of rheumatism. ${ }^{4}$ In Norway, Erik Petersen (1766-1835), a chairmaker by trade, was appointed public executioner for Trondheim in 1796, while also serving as an assistant in the town's hospital and, in 1808 , as an army surgeon during the war with Sweden. As we saw in the Introduction, at around the same time, the Bornholm executioner, Caspar Frederik Dirks, held the post in large part because of his medical credentials. When he threatened to resign in 1791, an army surgeon put in an application to replace him. ${ }^{5}$ However, the early decades saw the growing success of the orthodox medical profession in securing a monopoly on medical practice through the suppression of irregular, unlicensed healers, and the imposition of qualification requirements for public health positions. Therefore when, in 1818, Erik Petersen applied for a medical licence, he was turned down, despite his extensive experience in the field.

In his seminal study of professional and popular medicine in France between 1770 and 1830, Michael Ramsey notes how some executionerhealers tried adapting to the new realities regarding public health legislation and state-controlled health provision, and sought formal medical qualifications - with some success. During the Revolution, two executioner-bonesetters in Vannes and one in Nîmes took out patents as health officers. In 1820, the executioner for the department of Yonne pursued examinations to be a health officer. When, in 1819, an experienced executioner and bonesetter named Caron, formerly executioner in the Gironde, took on the role of executioner in Bordeaux, a local physician made a formal complaint. An investigation revealed that Caron had received a legitimate health officer's diploma in anticipation of becoming the executioner for Versailles, but subsequently fraudulently obtained a Paris university medical diploma. ${ }^{6}$ Reforms after 1830 further undermined the French executioner's position, though. In 1832, a law regarding the replacement of aged bourreaux began the process of reducing the number of executioners and also their assistants. 
During the 1840s, further changes reduced the pay of some executioners in a period when there were relatively few executions. For some, their subsidiary medical practice became more important, or, ultimately, their sole source of income. In 1852, for example, the ex-bourrean of Chalon-sur-Saône, Etienne-Théodore Cané, announced in the local press that he was a 'surgeon-dentist technician' offering orthopaedic bandages for hernias and supports for other deformities of the body. However, the French medical profession was hawk-eyed in its crusade to eradicate unlicensed medical practitioners. The general practitioners of Agen, for instance, made a formal complaint against the local bourreau, JeanBaptiste Champin, who had a large signboard on his house advertising his services as a 'bandagiste patenté' (licensed bandager), hernia sufferers being his principal clientele. ${ }^{7}$ Henri-Clément Sanson, Paris executioner between 1840 and 1847, recalled how his father Henri, who operated the Paris guillotine from 1795 to 1840 , had relied heavily on the medical formulas and recipes held by the Sanson family. His healing successes were so well known, he claimed, that eminent surgeons did not disdain from sending on patients to be healed. However, as Henri-Clément noted with frustration, in his own times, 'the rigour with which they were demanding that practitioners had diplomas removed from us a large part of our clientele' ${ }^{8}$

\section{The Criminal Corpse in Pieces}

As we have just seen, the executioner's role as healer staggered on into the mid-nineteenth century, but what of the trade in body parts, which used to be a central aspect of their ancillary medical and magical business? Human fat had been one of the most important substances in those states where the executioner had the right to dissect his victims. During the seventeenth century, in particular, it was traded and employed for medical purposes in Germany, Italy, France and Spain. The commerce in human fat was mostly medical, though there was some discussion about the magical (or diabolical) power of the meat of executed criminals, particularly in love magic rituals. ${ }^{9}$ It was deemed efficacious against contusions, broken bones, the scars of smallpox and wounds. In the early eighteenth century, one Italian charlatan sold an unguent called Balsamo del sole (Balm of the Sun) to treat cold and damp humours, attributed to the alchemist Giuseppe Borri (1627-1695), which purportedly contained human fat. A Roman charlatan named Lorenzo Sabatini sought 
permission to sell his expensive 'Balm of Human Fat' from the corpses of healthy men who had been executed or recently killed in accidents. It was for the cure of pneumonia and gout. ${ }^{10}$ However, the executioner's right to dissect criminal corpses was largely a thing of the past by the mid-eighteenth century. In 1742, the Augsburg executioner, Johann George Trenkler, was ordered, for instance, to hand over all criminal cadavers to the hospital for dissection by medical students. Five years later, he petitioned to have the right to dissect for the good of public health. It was the best source of poor sinners' fat, and he claimed, 'The whole town knows that by mixing a salve with human fat .... I have cured several patients of their nerve gout.'ll $\mathrm{He}$ was unsuccessful. In 1799, the Justice Committee in Turin, Italy, recommended compensating the city executioner the sum of 24 soldi (silver coins) for the income lost once he was forbidden to sell human fat. ${ }^{12}$ However, as Kathy Stuart has observed, 'the use of human fat was not particular to executioner medicine; executioners simply had privileged access to it'. ${ }^{13}$

During the second half of the eighteenth century, the influential Italian anatomy professor, Domenico Cotugno (1736-1822), still listed human fat as a remedy against gout or nervous sciatica, yet he affirmed that it was no more potent than other fats. What made the difference was its alleged scarcity and the power that people attributed to it. ${ }^{14}$ Prices were certainly high by the mid-eighteenth century. In 1761, the well-known Madrid apothecary, José Hortega, was selling it for the considerable sum of 160 reales de vellón per pound. The trade in pre-Revolutionary France was also a highly competitive business. One pharmacist advertised that he had fought the executioners and the apothecaries to be able to sell his human fat, which he boasted was better than that of the hangman because of the special seasoning he applied to stop it going rancid. ${ }^{15}$ Seventeenth- and early eighteenth-century medical texts that mentioned human fat circulated long after the substance was no longer readily available. Popular herbals and household guides, such as l'Agriculture et maison rustique, which went through numerous editions throughout the seventeenth century, and was no doubt consulted in homes for decades after, contained several references to using human fat in home remedies. It recommended mixing it with the herb elatine (waterwort) to ease the pain of gout, and noted it was also 'miraculous' in drawing out harquebus shot from the body. ${ }^{16}$

It is no surprise, then, that the commerce in human fat did not cease completely with the ending of the executioner's perquisite. While 
demand remained, so money was still to be made. If the executioner could no longer supply it, the new masters of the criminal corpse, the medical profession, were not beyond illegal trade in the substance, as was revealed by a sensational case in France. During the early nineteenth century, Paris medical students and their dissection theatre assistants, the garçons de l'amphithéatre, were found to be systematically draining and collecting human fat from the corpses they dissected and selling it illegally for a variety of purposes. The principal buyers were enamellers, and other craftsmen who used blow torches, because it was thought human fat produced a steadier, stronger flame compared with the legal supply of dog and horse fat. It was also sold as axle grease, and purchased by unorthodox healers and druggists as part of their pharmacopoeia. This public hygiene scandal was investigated by the authorities in 1813 , though to avoid raising public fears reporting restrictions were enforced, so the press did not get a whiff of the story at the time. Those culpable were sent to prison for 6 months. Two thousand litres of human fat were discovered in the care of a man at one of the medical schools, $400 \mathrm{~kg}$ in the possession of another, and smaller amounts in other hands at the dissection amphitheatre. ${ }^{17}$ The cholera expert, Charles Londe (1795-1862), recalled that during his student days in Paris a restaurant owner, who served large numbers of students, was sent to prison for having used human fat obtained from the garçons de l'amphithéâtre in his cooking. ${ }^{18}$

It is unlikely much of this Parisian fat made it into the distant French provinces, where demand also continued. In Lyon, after the death of the executioner Chrétien, people continued to resort to the city's pharmacies, requesting in vain 'la graisse de Chrétien'. In his 1869 book on natural and artificial body fats, the Montpelier physician L.-H. De Martin recalled the days when the bourreaux sold the 'graisse de pendu' to the credulous, lamenting 'if hanging has been abolished, credulity, alas! has not been'. A trade clearly remained for longer. A pharmacist from Montbrison in the Haute Loire wrote to the professional Journal de chimie médicale in 1860 to complain about the unfair competition he and his fellows faced from the church, itinerant charlatans and grocers. He wrote of one grocery shop he had visited that had fairly recently sold what was claimed to be human fat as part of its pharmaceutical products. ${ }^{19}$ One wonders about the real source and nature of the fat being sold in the Montbrison pharmacy. There had, no doubt, all along been a lively trade in passing off pig and goose fat as human. 
Other parts of the criminal corpse were desired more for their magical properties. The Franciscan, Bernardino of Siena (1380-1444), who preached against popular magic, noted the belief that to cure toothache one could touch the bad tooth with the tooth of a hanged man. It was recorded in late seventeenth-century France that to wear a wig made from the hair of hanged man soaked in the blood of a hoopoe would render one invisible. ${ }^{20}$ In early modern Germany, it was believed that the finger of an executed criminal brought luck to a household or business, and when placed in the stables, the horses would thrive. In the early sixteenth century, one Hans Moller von Dippertswald was prosecuted for fraud for selling the thumbs of executed thieves. ${ }^{21}$ In early modern Spanish inquisition records, we find people who covertly sought to steal for magical purposes parts of the criminal corpse as it was hanging or was displayed in public places. In Spain, it was forbidden to remove the hanging corpse until nightfall, so there was a period when raids could be made under darkness, depending on how quick the hangman was in taking down the corpse. In 1586, Ana de Yuso confessed how she and an acquaintance named Geronima 'had gone one night to a hanging and the said Geronima had asked a man who went with them to cut her a piece of the rope or a finger from the body and, when he had unsheathed his sword to do so, another man arrived and prevented him.' In another case, it was testified that the 'defendant was boasting that she had been to the scaffold of this city and had taken the heart from a hanged man ... and that the defendant was in the company of other women at the scaffold one morning and was unable to cut the hand from a dead man who was hanging there because people had come past'. ${ }^{22}$ As these suggest, stories and boasts of obtaining body parts probably far outnumbered the actual taking of body parts without the executioner's consent. And, of course, the Spanish switch to the garrotte in the eighteenth century ended such opportunities anyway.

In states where criminal corpses continued to undergo public postmortem punishment in the modern era, there were still opportunities for popular access to pieces of corpse. The Pomeranian High Court expressed concern about the problem in 1811: 'The general superstition of the common mob, that the possession of a limb of an executed malefactor or a piece of his clothing brings good luck, has led to frequent misappropriation of such items from these places.' It had received two recent reports of such activity. A journeyman cobbler had taken a bone from a body left on the wheel in Pollnow. It was reported from Saxony, 
in 1823, that within a week all the fingers, toes and clothes of an exposed criminal corpse at Schneeberg had been removed for magical and medical purposes. ${ }^{23}$ There are some examples in which the body pieces and the identity of the criminal were expressly related: something of the former notoriety of the criminal remained sealed and transmissible inside them. This is the case with people convicted for political crimes-revolutionaries and rebels who became heroic figures for the crowd. The story of the Tyrolean rebel, Andreas Hofer, executed in Munich in 1810, is a good example. Apparently, some soldiers attempted to get hold of a limb from his corpse as a protective talisman, but they were caught and punished. ${ }^{24}$

There is little evidence of people in England raiding gibbets for corpse pieces during the eighteenth or early nineteenth century. Only a handful of gibbetings took place after 1800, and the authorities went to considerable lengths to ensure there was no cutting down or tampering of gibbeted corpses for whatever purpose. The gibbet posts were often more than $10 \mathrm{~m}$ high and spikes were sometimes fitted around the base. ${ }^{25}$ However, up until the Anatomy Act of 1832, the policy of dissecting male criminal corpses provided potentially new opportunities for obtaining body parts for private purposes. There is no evidence in England of human fat being collected from the dissection room and sold as in Paris, though. As Elizabeth Hurren observes, apart from the skeleton and tanned skin, 'most human remains simply disappeared down the drain, as criminal flesh disintegrated into dusty sweepings' ${ }^{26}$ While skeletons ended up in museums and private collections, it was the skin that had the most diverse afterlife. Belts of tanned human skin, for instance, had long been used in medicine as a cure for labour pains. In the 1680s, the German physician, Johann Jacobi Waldschmidt, noted that it came highly recommended for this purpose, and a Danish pharmacopoeia of around the same date quoted the current price as 16 marks a piece. ${ }^{27}$ The trade in magic belts accordingly declined as executioners ceased to have control over the criminal corpse.

One of the most interesting biographies of a criminal corpse skin is that of the English murderer, Mary Bateman. She was a Leeds cunning woman found guilty of deliberately poisoning one of her clients in 1809 and was hanged by William Curry. Her corpse was publicly dissected, with $£ 80 \mathrm{l}$ s s being raised from entrance charges. At least one body part was circulated, with the tip of Mary Bateman's tongue finding its way into the curio collection of the governor of Ripon prison. ${ }^{28}$ 
More money changed hands for pieces of her tanned skin. Two books were commissioned to be bound in it, Sir John Cheeke's Hurt of Sedition: How Grievous it is to a Common Welth (1569), and Richard Braithwaite's Arcadian Princess (1635), which used to be in the library of Mexborough House, Yorkshire, but mysteriously went missing when the library was being catalogued for sale in the mid-nineteenth century. ${ }^{29}$ There was a long European tradition of covering books, often medical texts, in flayed human skin, a practice known as anthropodermic bibliopegy. In early nineteenth-century Britain, before the Anatomy Act of 1832, there was a vogue for covering published accounts of a murderer's trial with the skin from his or her corpse. ${ }^{30}$ This was the fate of William Corder's epidermis. Convicted for the sensational Red Barn murder case, he was executed at Bury St. Edmunds in 1828. 'The binding of this book is the skin of the murderer, William Corder,' states a note written in the copy, 'taken from his body and tanned by myself in the year 1828 . George Creed, surgeon to the Suffolk Hospital.'31

Small strips of Bateman's skin were also tanned and sold as curios. The York surgeon, Richard Hey, wrote to the Medical Times in 1856 to say that his grandfather had given several anatomical lectures using Bateman's body at Leeds infirmary, and his 'eccentric' father had kept a piece of her tanned skin. ${ }^{32}$ A farmer named John Andrew of Birstwith, North Yorkshire, also possessed one such piece in the 1850s. Later in the century, strips preserved in jars were still circulating in Yorkshire. ${ }^{33}$ Pieces of her skin were not only desired as curios, they also apparently accrued a reputation for having the power to ward off evil spirits. However, this is the only English example of criminal corpse skin being used for such magical purposes, and one suspects that Mary Bateman's reputation as a cunning woman was key to why her skin might have accrued such a reputation, rather than it being a criminal's skin per se. ${ }^{34}$

In late nineteenth century France, a skin scandal broke that echoed the fat scandal of 1813, revealing once again how the old perquisites of the executioner had passed on to the new 'honourable' custodians of the criminal corpse. In 1883, Michel Campi, who become known as 'the mysterious assassin of the Rue du Regard', confessed to cutting the throats of a retired Parisian advocate named Ducros and his elderly sister. Campi's past was surrounded in mystery, which he was keen to promote during the investigation, but he was executed the following year after a sensational trial. ${ }^{35}$ His body was taken for dissection, and his skeleton preserved and put on public display at the Broca Museum of the 
Laboratoire d'Anthropologie. The fate of his skin became something of a cause célèbre over the next few years. The national newspaper, Le Figaro, reported in a scoop, in November 1884, that the skin of Campi's right side and arm had been taken and tanned under the instructions of one Flandinette from the Laboratoire, who wanted to cover his account of the Campi case in the murderer's skin. ${ }^{36}$

A few years later, another skin scandal broke in the press regarding the corpse of the murderer Henri Pranzini, executed at the Roquette Prison, Paris, in August 1887. Some skin had been taken from his chest, tanned, and used to cover several wallets that were given to senior officials. A satirical verse on the scandal ran:

If you want to hold on to your skeleton,

Don't do like Pranzini.

Die in your bed

Rather than snuff it at the Roquette.

Your body will not be cut up,

In pieces for the Sûreté. ${ }^{37}$

Under pressure from the newspapers, the wallets were destroyed. One of those who had been gifted one, Marie-François Goron, Head of the Sûreté, wrote about the affair in his memoires, and expressed the view that the press had blown the matter out of all proportion. Despite Goron's best efforts, the garçon de l'amphithéatre involved in the transaction was dismissed by the Faculty for abetting in the taking of the skin from the dissection room. The poor man died shortly after-'truly the posthumous victim' of Pranzini, wrote Goron.

And what of the fate of Campi's skin that had been tanned for unknown purposes? In 1887, it was stated that his skin was now 'worth its weight in gold for some people'. ${ }^{38}$ And it was not just his skin that was desired. A journalist visiting the Broca Museum in 1886 reported that some finger bones and the thumb of the right hand had been stolen. When asked the reason why, the staff said they thought it was probably students seeking curiosities. ${ }^{39}$ Maybe or maybe not. Were the anatomy museums a new location, replacing the execution site, for the pilfering of criminal body parts for magical and medical purposes? As to Campi's skin, well, the Pitt Rivers Museum in England possesses a 'policeman's 
lucky amulet originally acquired in Paris' in 1889, which consists of a pierced sou attached to a small piece of tanned skin, supposedly Campi's, and a piece of cord purportedly from a hangman's rope. ${ }^{40}$

\section{The Fresh Body}

The trade in criminal body parts for medicine and magic was dependent on either the post-execution business of medical dissection or the illegal in situ theft of body parts when criminal corpses were left on display and unguarded long after execution. However, two other healing traditions that continued into the mid-nineteenth century were dependent on gaining access to the corpse minutes after the execution. One concerned the drinking of corpse blood, which will be discussed shortly, and the other was the touch of the hanged man's hand.

In 1854, the famed French novelist and campaigner for the abolition of capital punishment, Victor Hugo, wrote an account of the hanging of the murderer, John Tapner, the last person executed on Guernsey. Hugo was living on the neighbouring island of Jersey at the time and followed the case closely, writing a letter of protest to the British foreign secretary, Lord Palmerston. Tapner's execution was meant to be held in private, but some 200 ticket-holders were present. Although he did not attend, Hugo described the scene as reported to him: 'Tapner dead the law satisfied. It is now the turn of the superstitious; they never failed to come to the rendezvous which the gallows gives them. Epileptics came, and could not be prevented from seizing the convulsive hand of the dead man and passing it frantically over their faces. ${ }^{41}$ This is the last known case of people having access to the hanged man's hand for a cure in the British Isles, the last permitted example on mainland Britain being at a Warwick execution in 1845. A journalist described the latter instance:

The body remained suspended the usual interval of time, during which was enacted one of those disgusting scenes of vulgar superstition, which, in these days of boasted enlightenment, it was as extraordinary as it was revolting to behold. We allude to several females being allowed to ascend the scaffold, to have their wenned-necks rubbed by the still warm hand of the malefactor. ${ }^{42}$

The authors have found over two dozen cases of people requesting to be touched by the hand of a freshly hanged corpse at executions between 
the mid-eighteenth and mid-nineteenth centuries, mostly to cure swellings on the neck or head caused by goitre (enlarged thyroid gland), scrofula (infection of the lymph nodes, often associated with tuberculosis) and wens (sebaceous cysts). The hanged man's touch was primarily practised in southern England, though the notion that the hand of the freshly deceased, and of suicides in particular, could similarly cure was widespread. Related traditions also appear on the Continent. In the midnineteenth century, French Basque people continued to believe that the executioner of Pau could heal goitre by touching the patient's neck. ${ }^{43}$

The reason why the touch of the hanged man's hand was thought to be efficacious is unclear, and multiple explanations may have circulated in popular culture. The rules of magical transference may have been at work, with the illness being passed from the living patient to the still-warm hand of the hanging criminal, whose soul, not yet departed from his quivering body, would then take the ailment into the afterlife. Maybe there was no such spiritual connection, and it was merely an act of simple sympathetic magic. Once touched by the hand, the swelling would reduce as the buried or gibbeted corpse decayed and disintegrated. There was a similar widespread notion that warts would disappear by touching them with a piece of meat and then burying it. Why the executed criminal, as distinct from any other corpse? Perhaps it was considered extra-potent due to the redemptive quality of the criminal's last confessional moments on the scaffold. Or maybe the explanation is purely a pragmatic one, with executions offering the easiest access to a corpse so quickly after death. Knowing in advance the time and place of an execution enabled the sick to plan their intended appointment with the freshly deceased.

Access to the hanged man's hand was carefully controlled by the executioner and became one of his perquisites. Just before the corpse of James Morgan was cut down at a hanging in Maidstone in 1819, for instance, the hangman enabled a young woman to stand on the waiting coffin in order to be able to reach up and have the hand of the hanging corpse passed over a swelling on her throat. ${ }^{44}$ The hangman would usually take the hand of the corpse and administer the rubbings to the patients as they stood or sat on the scaffold. The condemned were aware that their bodies might be exploited in this way minutes after their death. In 1815, while on the Newgate scaffold awaiting his hanging, the forger, John Binstead, requested of the presiding clergyman that his hands would not be made available to those seeking a cure for 
wens. ${ }^{45}$ The process accrued magical elements, with the stroke sometimes being given nine times, three and nine being important numbers in folk magical ritual. There is clear evidence for the importance of contrasexual charming as well: in other words, that the cure would only work if a woman touched a male hand and vice versa. When Ann Norris and Samuel Hayward were hanged at Newgate on 27 November 1821, the Morning Post reported that 'Several men rubbed their necks and faces with the hand of the unfortunate female-while as many women went through the same ridiculous and indecent charm with those of the wretch Hayward. 46

The increasingly theatrical and ritualised nature of hangings towards the end of the eighteenth century, with the scaffold platform placed high above and at some distance from the curious crowds, gave the whole procedure of obtaining the stroke a formalised and official status. The clampdown on the practice began in the early nineteenth century, with the newspapers repeatedly requesting the authorities do something to suppress what was described as a barbaric superstition. However, it proved a remarkably tenacious practice, considering the ease with which the authorities could have stopped it, as they controlled every aspect of the execution procedure. The hangmen were reluctant to give up a valuable extra income, and the sheriffs, who were responsible for hiring and paying executioners, were reluctant to antagonise the small pool of hangmen. The eventual suppression of the practice was apparently primarily due to the growing influence of prison governors, as prisons became the sole location for executions during the nineteenth century. The authors have written at length about the hanged man's hand tradition in an article free to the public, ${ }^{47}$ so let us pass on to the matter of obtaining fresh blood at continental beheadings, which raises similar issues regarding state policy, spectacle and popular medical and magical tradition.

To the modern imagination, the drinking of a criminal's blood immediately after his execution might appear as some barbaric 'medieval' superstition or some grotesque story of diabolical ritual from the torture chambers of the witch trials, but how widely it was practised from the sixteenth to the early eighteenth century is unclear. Most of our recorded accounts concern the nineteenth century: some eighteen or so cases of the practice from late-eighteenth- and nineteenth-century Germany, nine or so cases from Sweden, four from Denmark and three from Norway. ${ }^{48}$ The last recorded instances across northern Europe were in the 1860s, 
while the last unsuccessful request to get blood from an executed criminal to heal epilepsy was made by a woman at Freiberg in $1908 .{ }^{49}$ As with the hanged man's touch, there were undoubtedly numerous other instances that we have not come across or which went unreported. The prevalence of the practice depended, of course, on execution techniques, and, as we saw in the Introduction, Sweden only switched from hanging to beheading in the early nineteenth century. Norway, likewise, abolished hanging in 1815 and turned to the chopping block, so in terms of popular execution magic and medicine, one door closed and other opportunities opened up as the blood ran freely. As with the hanged man's hand, what seems to be a macabre survival of superstition was actually a modern, state-enabled, popular medical tradition.

The pattern of demand for the practice also needs to be considered in the context of the significant reduction in executions in Scandinavia during the period, as sentences were increasingly commuted and imprisonment became the norm for capital offences. In Denmark, there were only 42 beheadings between 1841 and 1892, while in Sweden over 600 executions took place between 1800 and 1864, mostly concentrated in the early decades, with only 15 between 1866 and 1910. ${ }^{50}$ Thus, when a butcher named Marcusson and his accomplice in murder, Bottilla Nilsdottir, were due to be executed in Ystad, Sweden, in February 1851, a large number of people assembled to obtain their blood. It was noted, after all, that there had been no execution in Sweden for 8 years, and no execution in that province for 60 years. The pent-up demand was clearly huge. ${ }^{51}$

It is not clear to what extent blood-drinking was controlled by the executioner as one of his perquisites. There seems to have been a freefor-all on some occasions. Take this account given by the American travel writer, John Ross Browne, of a beheading in Hanau, near Frankfurt am Main, during his visit to the country in 1861:

Standing near the scaffold, in close proximity to the criminal, within the guard of soldiers, were six or eight men from the mass of the people, said to be afflicted with epilepsy. The moment the head was off these men rushed to the body with tumblers in their hands, caught the blood as it spouted smoking warm from the trunk, and drank it down with frantic eagerness! Their hands, faces, and breasts were covered with the crimson flood that ebbed from the heaving corpse. One man, too late to catch the blood as it spurted from the neck, took hold of the body by the shoulders, 
inclined it over in a horizontal position, poured out his tumbler full from the gory trunk, and drank it in a wild frenzy of joy! ${ }^{52}$

In most cases, though, one gets a clear sense of the procedure being curated by the executioner. At the beheading of Carsten Hinrich Hinz, at Tonning in April 1844, the executioner allowed the epileptic son of a farmer from Oldenburg to drink some of the criminal's blood. Likewise, at a beheading in Hanover in 1857, it was reported that a number of epileptics came forward and the executioner 'readily gave it to them' ${ }^{53}$ From Sweden, we have one example in January 1833, when, in the parish of Hällefors in Västmanland, people came to acquire blood from the executioner at the beheading of the murderer, Olof Liljeblad. ${ }^{54} \mathrm{~A}$ degree of formal process was exhibited at a public execution in Mainz, in 1802, where the executioner's assistants caught the blood in a beaker and then some of the crowd were allowed to come forward to drink it. Again, in Berlin in 1864, the executioner's assistants distributed white handkerchiefs dipped in the victim's blood, selling them for two thalers a piece. ${ }^{55}$ By custom, it was not only the authorities who dictated access to the criminal's blood: in Scandinavia, the sick also occasionally sought the permission of those awaiting beheading. The day before an execution was due to take place in Dahlby in Scania, Sweden, numerous sick people visited the jail and obtained from the criminal permission to drink his blood-'a needful proceeding to render the loathsome draft efficacious'. ${ }^{56}$ In Assens, Denmark, in August 1856, two girls aged 15 and 17 collected and drank the warm blood of Peder Olsen, who had murdered a young woman. When a magistrate questioned them regarding their behaviour, they testified that there was nothing wrong: they had received the signed permission of the condemned to drink his blood. Olsen's sentence had stated that his head was to be displayed on a pike, though this was dropped on appeal. Olsen apparently found the state's use of his body more objectionable than the people's use of his blood. ${ }^{57}$

Pressure from the press and commentators, who decried such public exhibitions of 'credulity' and 'ignorance', led to the suppression of the practice during the mid-nineteenth century. A case of blood-drinking at an execution in Örebro, Sweden, in 1846, led the newspaper Aftonbladet to describe it as 'foul' superstition, for example. ${ }^{58}$

As with the hanged man's hand, there were also law and order concerns about allowing the practice. The task of suppressing the custom was not easy. In the 1851 Ystad case mentioned above, the authorities 
were determined not to let the crowd, armed with their cups, pots, bowls and pans, get access to the blood. Soldiers ringed the execution platform, and at the moment of the beheading, they drove back the surging crowd with their rifle butts. It was reported that the struggle left some 200 people badly injured and many others bruised. By the time some of the blood-seekers had broken through the cordon, the corpses and heads had already been removed and carried away under cavalry escort. The authorities even went to the effort of removing the earth and turf splattered by the blood.

The drinking of blood to cure epilepsy, like so many folk medical traditions, including the aforementioned stroking of a dead man's hand, dates back to antiquity. In his Natural History, Pliny the Elder (d. 79 AD) described how epileptics were drawn to gladiatorial spectacles in the arenas-just as they were to the scaffold in the nineteenth century. 'While the crowd looks on,' he observed with disgust, 'epileptics drink the blood of gladiators, a thing horrible to see ... they think it most efficacious to suck as it foams warm from the man himself. ${ }^{59}$ According to ancient Galenic medicine, which held sway through much of the early modern period, blood was one of the four humours and so sometimes more or less blood was required to restore health. ${ }^{60}$ As one late seventeenth-century treatise explained, 'good blood is that which is temperate in the first Degree, not too thin not too thick; not sharp nor biting, not bitter, not salt, not sour' ${ }^{61}$ According to Galenic medicine, an excess or plethora of blood, or corrupted blood, was a health problem, leading to the widespread practice of blood-letting. However, blood cures were not dependent on humoral theory. That arch-critic of Galenic medicine, Paracelsus, also recommended blood from a decapitated man drunk at certain astrologically propitious moments as one of several chemical cures for epilepsy, including the ingestion of ground mistletoe or peony seeds. ${ }^{62}$

Some eighteenth- and nineteenth-century German and Scandinavian descriptions of execution blood-drinking show that the ingestion of the blood alone was considered insufficient to effect a cure. Having imbibed from the blood spurting from the corpse's neck, the epileptics had to run fast, often spurred on or supported by family, friends, or bystanders, until they fell down senseless. This therapeutic method was reported in Dresden in June 1755 and in Hanover in 1812. In Zwickau in December 1823, several people, mostly children, drank from a pot full of the executed criminal's blood and were then whipped and 
obliged to run across a field. ${ }^{63}$ Two cases from Denmark demonstrate a similar procedure. The first took place at Skælskør in 1823, and was famously described by the storyteller, Hans Christian Andersen. The second occurred in 1834, at the execution in Hjordkær, North Schleswig, of H.S. Fallesen for murdering his bride. Three epileptics were allowed to drink his blood and were then made to run. ${ }^{64}$ In Dahlby, in Scania, no fewer than 70 individuals, suffering from different ailments, came to drink the criminal's blood. Those who managed were then 'seized hold of by two of the bystanders, by whom they are run backwards for some little distance, when the cure is supposed to be effected'. ${ }^{65}$ The cure could end tragically, as happened in Stralsund in 1814, when, after having been bound between two horses 'and pulled away at a breakneck gallop', the patient collapsed and died. ${ }^{66}$

A folklore record of the practice from Västergötland, Sweden, explained in scientific fashion that, after having gulped down the blood, people had to run to let the fluid circulate in their own blood and so be better absorbed into it. ${ }^{67}$ This notion echoed theories of the blood contained in early modern medical literature. The seventeenth-century Paracelsian chemist, Johann Schröder, wrote that, when drunk, blood caused a 'violent motion' of the patient's own blood and a copious sweating. The doctor explained that it had to be given cautiously to epileptics, because 'it not only brings a Truculency to the takers, but also the Epilepsie'. ${ }^{68}$ The theories about epilepsy of another physician, Georg Ernst Stahl (1659-1734), help us to understand this ambivalence. Discussing epilepsy as the result of the soul's attempt to expel plethoric humours or intrusive substances, he listed amenorrhoea in women among the causes of the sickness, but also an accumulation of blood in some organs. ${ }^{69}$ Thus, good blood could cleanse the unbalanced body, but an excessive dose could be equally damaging.

There is some evidence during the early nineteenth century that epileptics continued to be referred to the scaffold by physicians. The old humoral and Paracelsian medical theories had been largely abandoned in orthodox medicine, but new or updated notions of psychological and emotional influence on the body seemed to explain the apparent beneficial effect of execution blood. The influential eighteenth-century medical writer, William Cullen, referenced Pliny's account of the gladiators when trying to explain the apparent success of blood-drinking. 'As the operation of horror is, in many respects, analogous to that of terror,' he explained, 'several seeming superstitious remedies have been employed 
for the cure of epilepsy; and, if they have ever been successful, I think it must be imputed to the horror they had inspired.' The same psychological efficacy of spectacle and terror was attributed to the hanged man's hand cure. ${ }^{70}$ This interpretive shift is evident from a case at Stockhausen, Hanover, in 1843, where several epileptics gathered at an execution with their mugs. They were initially denied access on the advice of a local medical man, who declared the cure ineffectual, but they subsequently secured a certificate from medical professors at Göttingen University, to the effect that drinking the blood would have a beneficial 'psychological' effect. ${ }^{71}$ John Ross Browne discussed the practice of execution blooddrinking with 'intelligent' German acquaintances, 'who certainly do not share in the superstition, but who still maintain that there may be some reason in it'. The argument they put forward was that, epilepsy being a nervous disease, the shock of witnessing the execution and the act of drinking from the corpse could jolt the nervous system in a beneficial way. $^{72}$

We need to consider whether and why an executed criminal's blood was considered more potent than other people's blood. Maybe beheadings were merely the most convenient legal means of obtaining fresh blood. It is not exactly easy, after all, to obtain copious quantities of warm fresh human blood without resorting to murder. In countries where beheading was not practised, we find epileptics resorting to drinking their own blood. In 1863, for example, a doctor in north-western Scotland recorded that he had seen several epileptics drinking small quantities of their own blood to cure themselves. ${ }^{73}$ Animals' blood could also act as a substitute. As with the hanged man's hand, there was, then, undoubtedly a pragmatic element to resorting to the scaffold corpse. However, there were other possible elements at play for why an execution corpse was sought. Galenic humoral theory and Paracelsian notions, both of which filtered into popular medical conceptions, allowed that the heightened passions and emotions of condemned criminals could change the quality of the blood coursing through their bodies. The Danish examples of requesting permission from the condemned criminal provide further pause for thought. Were they merely a demonstration of decency and respect? Or were the applicants fearful of retribution from the future restless, outraged spirit of the condemned? Was the blood thought to be filled with the grace of repentance and purged sin?

Some blood-drinking operated through ritual. In other words, the curative potency of the criminal blood was activated or enhanced by 
magical or religious observance. In June 1861, a poor woman suffering from epilepsy obtained permission to go to Trogen, Switzerland, and attend an execution in order to try the blood remedy. She was advised to drink it warm in three sips, while repeating the holy trinity. Unfortunately, once at the scaffold, a new epileptic attack prevented her from imbibing the fresh blood. ${ }^{74}$ It is clear, furthermore, that the executioner's role was not always merely that of a custodian. With the hanged man's hand, the efficacy of the cure sometimes depended on it being performed by the executioner, hence the notion, in France and Belgium, that the executioner's stroke using his own hand was potent in itself. In some Scandinavian cases, there is evidence that cunning folk also played a mediation role. At the execution of Carl Petersson in Skarpåsen, southern Sweden, in January 1847, a soldier named Olaf Magnusson Bly apparently witnessed two wise women, amongst others, gathering around the corpse to collect the healing blood. When the fluid ran out, he added, the women milked the carotid to get extra drops. ${ }^{75}$ At an execution in 1863, carried out by Norway's penultimate state executioner, Samson Isberg, in Etterstad, near Oslo, a wise woman came with three pots in order to fill them with blood to use against epilepsy. ${ }^{76}$

However, no agency was required in other overtly magical uses of execution blood that were not concerned with healing. According to German folklore, if bakers, innkeepers and merchants dipped a piece of linen soaked in the blood of a beheaded criminal into their dough, beer or brandy barrels, they would attract a greater number of customers. ${ }^{77}$ At the beheading of the murderer, Treiber, in Munich in September 1852, as well as the usual epileptics, some people sought the blood as they thought it would enhance their chance of drawing lucky numbers in the lottery. Two years later, at an execution in the German town of Adelsheim, people gathered to get some blood because it was thought to act against sickness and evil forces, keeping witches away from houses and stables, and protecting against lightning. ${ }^{78}$

Thus, there clearly was something more than just convenience in the resort to execution blood. Any old blood would not do in magical terms. This leads to the consideration of whether further potency accrued to specific executed people. In other words, did unusual notoriety or celebrity further enhance the power of the blood? When the national revolutionary student, Karl Ludwig Sand, was executed in Mannheim in 1820 , people were reported 'to have stormed at the scaffold, soaked up his blood with kerchiefs, broken up the stool on which he had sat, 
and distributed the pieces'. Evans has argued that the episode might be either 'a political adaptation of the tradition', or simply just another case of medical employment of blood. ${ }^{79}$ Nevertheless, it is undeniable that individual identities could exercise a certain charm. An account from Catholic southern Europe, where cases of blood-drinking were rarely attested, seems to confirm the value of blood when taken from particularly respected executed people. The source is Italian, but it deals with Catalan events. In May 1894, in Barcelona, after the execution of six anarchists, who were garrotted, a woman plunged her handkerchief in the blood dripping from the corpses and then she carefully wrapped it in a newspaper, as if it were a special talisman. Then she invited one of the journalists to follow her example. ${ }^{80}$

There has been a tendency to assume that criminal corpse medicine and magic largely ended as the early modern period drew to a close, thanks to the 'usual' Enlightenment mix of popular education, civilising campaigns, religious rationalism, judicial policy and scientific advancements. As recent studies of magic and witchcraft have shown, though, this is a narrative dependent on a now-debunked disenchantment thesis. However, as the history of the hanged man's hand and blood-drinking demonstrates, the policies of the modern state could inadvertently promote and enable popular magical and medical practices, as well as hamper and suppress them. The enthusiasm for blood-drinking was promoted in the nineteenth century by the shift to execution practices that were thought to be more humane. The hanged man's hand continued into the mid-nineteenth century due, in part, to pragmatic administrative decisions about ensuring a limited pool of hangmen were kept happy. Some traditions declined as an inadvertent consequence of changing execution practices, rather than popular rejection or authoritarian suppression.

\section{Notes}

1. Cited in Richard D.E. Burton, Blood in the City: Violence and Revelation in Paris, 1789-1945 (2001), p. 101.

2. Kathy Stuart, Defiled Trades and Social Outcasts: Honor and Ritual Pollution in Early Modern Germany (Cambridge, 1999), p. 225; Spierenburg, Spectacle of Suffering, pp. 188-190. See also, Lisa Silverman, Tortured Subjects: Pain, Truth, and the Body in Early Modern France (Chicago, 2001).

3. El Globo, 23 December 1906. 
4. Jules Drivon, 'Histoires de Bourreaux', Revue d'Histoire de Lyon 11 (1912), p. 194.

5. Carøe, Bøddel og Kirurg, pp. 43-44, 49-50.

6. Michael Ramsey, Professional and Popular Medicine in France 1770-1830: The Social World of Medical Practice (Cambridge, 1988), pp. 87, 89.

7. Frédéric Armand, Les bourreaux de France: du Moyen âge à l'abolition de la peine de mort (Paris, 2012), p. 214.

8. H. Sanson, Sept générations d'exécuteurs 1688-1847: Mémoires des Sanson (Paris, 1863), vol. 6, pp. 158-159.

9. See, for example, F. Suárez de Ribera, Remedios deplorados probados en la piedra lydio de la experiencia (Madrid, 1732), p. 118.

10. David Gentilcore, Medical Charlatanism in Early Modern Italy (Oxford, 2006), p. 221; Piero Gambaccini, Mountebanks and Medicasters: A History of Italian Charlatans from the Middle Ages to the Present (Jefferson, 2004), p. 24.

11. Kathy Stuart, Defiled Trades and Social Outcasts: Honor and Ritual Pollution in Early Modern Germany (Cambridge, 1999), p. 157.

12. Antonio Bortolotti, Cagliostro e l'arte di sanare nel '700 (Milan, 1995), p. 73.

13. Stuart, Defiled Trades, p. 158.

14. Domenico Cotugno, A Treatise on the Nervous Sciatica (London, 1775), pp. 107, 128. See also Sugg, Mummies, pp. 232-234.

15. Javier Puerto, Medicamentos legendarios: Mito y ciencia en laterapéutica clásica (n.d.), p. 154; Evariste Thévenin, Entretiens populaires (Paris, 1863), p. 114.

16. Charles Estienne and Jean Liébault, L'Agriculture et maison rustique (Paris, 1665), p. 181.

17. A.J.B. Parent-Duchatelet, Hygiène Publique (Paris, 1836), 2 vols, vol. 1, pp. 22-25.

18. Charles Londe, Nouveaux éléments d'hygiène, 2nd edition (Paris, 1838), Vol. 2, p. 154.

19. Drivon, 'Histoires de Bourreaux', 194; L.-H. De Martin, Des corps gras naturels et artificiels (Paris, 1869), p. 187; Journal de chimie médicale, 4th S, Vol. 7 (1861), 100.

20. Franco Mormando, The Preacher's Demons: Bernardino of Siena and the Social Underworld of Early Renaissance Italy (Chicago, 1999), p. 96; Jean Baptiste Thiers, Traite des superstitions (Paris, 1697), Vol. 1, p. 380.

21. Hermann Leberecht Strack, The Jew and Human Sacrifice: Human Blood and Jewish Ritual. An Historical and Sociological Inquiry (New York, 1909), p. 73; Gary K. Waite, Heresy, Magic and Witchcraft in Early Modern Europe (Basingstoke, 2003), p. 135. 
22. María Tausiet, Urban Magic in Early Modern Spain: Abracadabra Omnipotens (Basingstoke, 2014), pp. 93-94.

23. Evans, Rituals of Retribution, pp. 93-94; Keller, Scharfrichter, p. 232.

24. Strack, The Jew and Human Sacrifice, p. 74.

25. Sarah Tarlow, 'The Technology of the Gibbet', International Journal of Historical Archaeology 18 (2014), 681, 696.

26. Elizabeth Hurren, Dissecting the Criminal Corpse: Staging Post-Execution Punishment in Early Modern England (Basingstoke, 2016), p. 258.

27. Johann Jacobi Waldschmidt, Operum medico-practicorum (n.p., 1717), Vol. 1, p. 521; 'Physician, Apothecary, and Hangman', British Medical Journal, 27 December 1913, p. 1641.

28. Doncaster Gazette, 24 June 1870; Leeds Mercury, 2 February 1904.

29. Edinburgh Evening News, 2 January 1886.

30. Deborah Lutz, Relics of Death in Victorian Literature and Culture (Cambridge, 2015), pp. 97-100.

31. The East Anglian, N.S. 1 (1885-1886), p. 295.

32. Medical Times and Gazette, 1 November 1855, pp. 443-444.

33. Leeds Mercury, 3 February 1904; J. Turner Horsfall, Yorkshire Notes and Queries (Bingley, 1888), Vol. 1, pp. 63-64.

34. Davies, Murder, Magic, Madness, p. 34.

35. H.B. Irving, Studies of French Criminals of the Nineteenth Century (London, 1901), pp. 141-151.

36. Le Figaro, 24 November 1884.

37. Les mémoires de M. Goron: Ancien chef de la Sûreté (Paris, 1897), pp. 179, 178. See also, G. Variot, 'Remarques sur l'autopsie et la conformation organique du supplicié Pranzini et sur le tannage de la peau humaine', Bulletins et Mémoires de la Société d'anthropologie de Paris 10 (1929), pp. $42-46$.

38. Paul Eudel, L'hotel Dronot et la curiosité (Paris, 1887), p. 249.

39. Le Figaro, 17 November 1886.

40. http://web.prm.ox.ac.uk/amulets/index.php/saints-amuletl/.

41. The Works of Victor Hugo: Things Seen and Essays, vol. 14 (New York, 1907), p. 241.

42. Royal Leamington Spa Courier, 19 April 1845.

43. Francisque Michel, Le Pays Basque: Sa population, sa langue, ses moeurs (Paris, 1857), p. 160.

44. New-England Galaxy, 18 June 1819.

45. John Ashton, Social England under the Regency (London, 1890) vol. 2, p. 60. Our thanks to Alice Dolan and Anne Murphy for this reference.

46. Morning Post, 28 November 1821. Our thanks to Naomi Clifford for this reference. On Norris, see Clifford's forthcoming book Unfortunate Wretches. 
47. Owen Davies and Francesca Matteoni, 'A virtue beyond all medicine': The hanged man's hand, gallows tradition and healing in eighteenth- and nineteenth-century England', Social History of Medicine 28 (2015), 686-705: http://shm.oxfordjournals.org/content/early/2015/05/01/shm.hkv044. full.pdf+html.

48. See Francesca Matteoni, 'The Criminal Corpse in Pieces', Mortality 21 (2016), 1-12.

49. Oppelt, Über die Unehrlichkeit des Scharfrichters, pp. 753-754.

50. Hornum, 'The Executioner', pp. 70-71.

51. Sandusky Register, 10 March 1851.

52. J. Ross Browne, An American Family in Germany (New York, 1867), p. 132. The case is also noted in Eduard Stemplinger, Antike und Moderne Volksmedizin (Dieterich, 1925), p. 61; Albert Hellwig, Verbrechen und Aberglaube; Skizzen aus der volkskundlichen Krimminalistik (Leipzig, 1908), p. 67.

53. Strack, The Jew, p. 72; New Albany Daily Register, 10 November 1857.

54. Nils Helger, Hällefors socken: hembygdsbeskrioning $i$ historisk framställning (Falund, 1945), p. 74.

55. Evans, Rituals, pp. 90, 93. Albrecht Keller, Der Scharfrichter in der Deutschen Kulturgeschichte (Hildesheim, 1968), pp. 232, 217.

56. Llewellyn Lloyd, Peasant Life in Sweden (London, 1870), p. 159.

57. Northampton Mercury, 30 August 1856. Archival material on the case can be found at http://boyebanden.dk/mordet-p-niels-hansen/eksekveringaf-dommen-1856.html.

58. Aftonbladet, 12 August 1846.

59. Shaun R. McCann, A History of Haematology: From Herodotus to HIV (Oxford, 2016), p. 4.

60. D. Cassano and C. Colucci d'Amato, "The moon" and "the blood": Two emblematic symbols in headache and epilepsy according to scientific traditions of the Salerno Medical School and popular medicine in southern Italy', Journal of the History of the Neurosciences: Basic and Clinical Perspectives 1 (1992), 97-110.

61. A Treasure of Health. By Castor Durante Da Gualdo ... Translated out of Italian (London, 1686), p. 46.

62. Edelgard E. DuBruck, 'Theophrastus Bombastus von Hohenheim, Called Paracelsus: Highways and Byways of a Wandering Physician (14931541)', Fifteenth-Century Studies 25 (2000), p. 5.

63. Keller, Der Scharfrichter, p. 232; Evans, Rituals, pp. 90-91.

64. Hermann Leberecht Strack, The Jew and Human Sacrifice: Human Blood and Jewish Ritual. An Historical and Sociological Inquiry (New York, 1909), pp. 70-71; U. Brodersen, 'Henrettet i Aabenraa'; http://dengang.dk/artikler/2171. 
65. L. Lloyd, Peasant Life in Sweden (London, 1870), p. 159.

66. Wolfgang Oppelt, Über die Unehrlichkeit des Scharfrichters (Lengfeld, 1976), pp. 752-53; Evans, Rituals, p. 91.

67. Nordiska Museet Arkivet, 25840. See also, for executed criminals' blood as a cure for epilepsy: NMA 30802, 30803, 23500, 28800, 23504.

68. J. Schröder, Zoologia. Trans. Anon (London, 1659), p. 48. See also, Sugg, Mummies, pp. 56-57.

69. Francesco Paolo De Ceglia, 'The Blood, the Worm, the Moon, the Witch: Epilepsy in Georg Ernst Stahl's Pathological Architecture', Perspectives on Sciences 12 (2004), 1-28.

70. William Cullen, First Lines of the Practice of Physic (Edinburgh, 1791), vol. 3, p. 365; Davies and Matteoni, “"A Virtue beyond all medicine”, 7.

71. Evans, Rituals, p. 92.

72. Browne, American Family, pp. 132-133.

73. Arthur Mitchell, 'On Various Superstitions in the North West Highlands and Islands of Scotland, especially in Relation to Lunacy', Proceedings of the Society of Antiquaries of Scotland 4 (1863), p. 273.

74. Ernst Ludwig Rochholz, 'Gold, Milch und Blut: Mythologisch', Germania: Vierteljahrsschrift für deutsche Altertumskunde 7 (1862), 414; Albert Hellwig, Verbrechen und Aberglaube, pp. 67-68. See also, Wolfgang Oppelt, Über die Unehrlichkeit des Scharfrichters (Lengfeld, 1976), p. 753; Oskar von Hovorka and Adolf Kronfeld, Vergleichende Volksmedizin; eine Darstellung volksmedizinischer Sitten und Gebräuche, Anschaunngen und Heilfaktoren, des Aberglaubens und der Zaubermedizin (Stuttgart, 1908), p. 217.

75. See the website: http://www.genealogi.se/avrattade-start.

76. Ingjald Reichborn-Kjennerud, Voir gamle trolldomsmedisin (Oslo, 1947), vol. 5, p. 65; Ernst Westerlund Selmer, Festskrift til Hjalmar Falk: 30. desember 1927, fra elever, venner og kolleger (Aschehoug, 1927), p. 30.

77. Strack, The Jew and Human Sacrifice, p. 73.

78. Catholic Telegraph, 25 September 1852; Evans, Rituals, p. 92.

79. Evans, Rituals, pp.91-92; Oppelt, Über die Unebrlichkeit des Scharfrichters, p. 754 .

80. N. Alpaghi, 'Il sangue dei giustiziati in Spagna', Archivio delle tradizioni popolari 13 (1894), 453. 
Open Access This chapter is licensed under the terms of the Creative Commons Attribution 4.0 International License (http://creativecommons.org/licenses/by/4.0/), which permits use, sharing, adaptation, distribution and reproduction in any medium or format, as long as you give appropriate credit to the original author(s) and the source, provide a link to the Creative Commons license and indicate if changes were made.

The images or other third party material in this chapter are included in the chapter's Creative Commons license, unless indicated otherwise in a credit line to the material. If material is not included in the chapter's Creative Commons license and your intended use is not permitted by statutory regulation or exceeds the permitted use, you will need to obtain permission directly from the copyright holder.

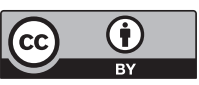

